\title{
The Influence of Individual Characteristics, Training Content and Manager Support on On-the-Job Training Effectiveness
}

\author{
Hadziroh IBRAHIM ${ }^{1}$, Md. Lazim Mohd ZIN² ${ }^{2}$ Punitha VENGDASAMY ${ }^{3}$
}

Received: August 01, 2020 Revised: September 28, 2020 Accepted: October 05, 2020

\begin{abstract}
The study examines the influence of individual characteristics, training content, and manager support on the effectiveness of on-the-job (OJT) training in the banking and finance industry. A simple random sampling technique was used to select the samples. Questionnaires were distributed to respondents in order to obtain the data. Using cross-sectional data obtained from 396 respondents in Bank A in Malaysia, the multiple regression results show that self-efficacy, motivation to learn, training content, and manager support have positive influence on OJT training effectiveness. Among all these factors, manager support is very highly correlated with OJT training effectiveness. The findings have given fruitful insight of the crucial roles of OJT training in the respective bank, particularly to bring forward the roles of systematic design and implementation of OJT training. This study is not only expanding knowledge in OJT and training, but offers managers practical insights in developing good OJT training program by considering employees need, capabilities, skills and job requirement. Furthermore, this study also provides a valuable framework in identifying the effectiveness of OJT training program for certain jobs. Further discussion of the research findings and its implications to theoretical knowledge of training and managers are promised at the end of the article.
\end{abstract}

Keywords: Training Effectiveness, Self-efficacy, Motivation to Learn, Training Content, Manager Support

JEL Classification Code: M10, M19, M53, O15

\section{Introduction}

In most organizations, training has been implemented as the most effective method in upgrading employees' knowledge and skills, so that they are able to perform better at work, which inadvertently lead to organizational success. On-the-job training (OJT) is one of various training methods that focus on a hands-on training of teaching skills, knowledge, and competencies needed for employees

${ }^{1}$ First Author and Corresponding Author. Senior Lecturer, School of Business Management, College of Business, Universiti Utara Malaysia, Malaysia [Postal Address: 06010 Sintok Kedah, Malaysia] Email: hadziroh@uum.edu.my

${ }^{2}$ Associate Professor, School of Business Management, College of Business, Universiti Utara Malaysia, Malaysia.

Email: lazim@uum.edu.my

${ }^{3}$ Human Resources and Compensation \& Benefits Manager, AXA AFFIN Life Insurance Berhad, Kuala Lumpur, Malaysia.

Email: punitha@kenanga.com.my

(c) Copyright: The Author(s)

This is an Open Access article distributed under the terms of the Creative Commons Attribution Non-Commercial License (https://creativecommons.org/licenses/by-nc/4.0/) which permits unrestricted non-commercial use, distribution, and reproduction in any medium, provided the original work is properly cited. to perform any jobs within an organization. This method provides a good training experience to employees because they can learn in an actual environment where they have to practice the knowledge and skills obtained during their training. As noted by Noe and Kodwani (2018), OJT is developed based on the fundamental ideas of applying the existing workplace tools, machines, documents, equipment, and knowledge to teach an employee how to effectively do their job. In short, OJT takes place within the employee's normal job environment and they will learn all aspects of skills and knowledge required in their actual work.

Banks and financial institutions in Malaysia invest a large amount of money, resources and technology for training purposes in building and enhancing employees' skills and knowledge. There are two main training approaches commonly used by these institutions to train their employees. It is either by using off-the-job training methods or OJT training methods. However, the effectiveness of OJT training is often questioned due to lack of systematic study that examines its potential benefits to employees in enhancing their job performance. Therefore, there are several factors that need to be studied that may encourage employees to participate in OJT training. Hence, this study 
aims to examine the effectiveness of OJT training among employees in the banking and finance industry in relation to four predictors including self-efficacy, motivation to learn, training content, and manager support.

\section{Literature Review}

\subsection{Conceptual Definition of On-the-Job Training Effectiveness}

Training effectiveness is defined as any enhancement or improvement on knowledge, skill, attitude and behavior (EL Hajjar \& Alkhanaizi, 2018; Wen \& Lin, 2014). There are two common measures of training effectiveness, which includes learning outcomes and job performance. However, the learning outcomes have been used in many empirical researchers (Tziner et al., 2007; Mathis \& Jackson, 2010; Wen \& Lin, 2014). Learning outcomes are referred as training goals, either in the forms of quantitative (financial performance, training marks) or qualitative goals (knowledge and skills acquisition) (Tziner et al., 2007). The learning outcomes also measure what the trainees have learned and what they have not to further improve future training (Kraiger et al., 1993). In this study, training effectiveness of OJT was measured by learning outcomes. The learning outcome of OJT is to measure trainee's ability to apply the knowledge and skills learned in the OJT to his or her jobs.

\subsection{Individual Characteristics and Training Effectiveness}

With regard to individual characteristics and training effectiveness, previous researchers have classified individual characteristics either as trainee's trait such as self-efficacy, consciousness, and goal orientation, or trainee's motivation, such as motivation to learn and instrumentality of training (Tziner et al., 2007). In other studies, trainee characteristics are also defined as the qualities, which trainees bring along to the training situations (Sahoo \& Mishra, 2019; Wen \& Lin, 2014). These include trainees' capabilities, such as mental ability and intelligence, personality traits motivations, values and interests, as well as emotions and perceptions (Sahoo \& Mishra, 2019). For instance, Tracey and Tews (1995) indicated that individual characteristics such as ability to learn and acquire new knowledge and skills have crucial effects on employees' ability to apply any training outcomes into their actual jobs.

The current study assesses the effects of trainee characteristics in terms of trainees' self-efficacy and motivation to learn. Self-efficacy is trainee's attribute, which is defined as the trainees' belief that they can successfully achieve training goals and applying learned knowledge and skills (Mathieu et al. (1993). Empirical research has established the direct link between self-efficacy and training effectiveness (Mathieu et al., 1993; Tziner et al., 2007; Wen \& Lin, 2014). For example, trainees with a strong sense of self-efficacy are seen to be more committed learners and motivated person (Mathieu et al. (1993). The link was justified on the fundamental premise that trainees' efforts to develop the self-encouragement in the training would encourage them to apply learned skills and knowledge. In other context, previous studies also claimed that individual self-efficacy has strong impacts on creativity (Kim, 2019), social entrepreneurial intention (Akhter et al., 2020), and women self-reliance in productive economic activities (Suminah \& Anantanyu, 2020).

According to Tziner et al., (2007) self-efficacy is strongly associated with trainees in any training programs. In a similar vein, Wen and Lin (2014 found positive influence of self-efficacy on training outcomes. In empirical study by Wen and Lin (2014), a surveyed study conducted among full-time employees from broad industries in Taiwan found that motivation to learn was positively related to training outcome such as trainees' ability to apply knowledge in actual job. Furthermore, such trainees were more selfmotivated and aimed for self-improvement in the future job. In the training process, these attributes are crucial to ensure training effectiveness. Trainees with positive characteristics performed well on their jobs and perceived training as useful in improving their performance. Therefore, it is hypothesized that:

\section{$\boldsymbol{H}_{\boldsymbol{I}}$ : Self-efficacy is positively related to OJT training} effectiveness.

H2: Motivation to learn is positively related to OJT training effectiveness.

\subsection{Training Content and Training Effectiveness}

Training content is defined as a collection of teaching and learning materials related to the goals and objectives of the training given to the trainees (Mathieu et al., 1993; Velada et al., 2007). Most researchers in the area of training effectiveness insisted that relevance of training contents is important for measuring the effectiveness of training program. Notably, content relevance is importance for ensuring the learning materials are closely relevant to the transfer task and skills or knowledge to be learned (Alias et al., 2019; Burke \& Hutchins, 2008).

On the basis of validity of the training contents, Zhao and Namasivayam (2009) stated that training effectiveness is influenced by the capability of trainees to learn training modules, topics and contents and then apply the learned skills and knowledge in their jobs. Empirically, training content and training effectiveness were found to have significantly 
Hadziroh IBRAHIM, Md. Lazim Mohd ZIN, Punitha VENGDASAMY I

positive linkages (Mathis \& Jackson, 2006; Mathieu et al., 1992; Wen \& Lin, 2014). For example, Mathis and Jackson (2006) found that training purposes and contents were related positively to training goals. Similarly, a study by Wen and Lin (2014) found that training content was positively related to training outcome (training goals).

In addition, a study by Alias et al., (2019) among managerial employees in the government department also found that training content was positively related to training effectiveness. Therefore, it is interesting to mention here that the effectiveness of training programs is highly dependent upon the training content. This is because the training content would help trainees to understand the objectives of the training, and indirectly will influence their commitment to learn and apply skills in their jobs (Mathis \& Jackson, 2006). On the basis of these arguments and the aforementioned literature, the following hypothesis is posited:

H3: Training content is positively related to OJT training effectiveness.

\subsection{Manager Support and Training Effectiveness}

Manager support is described as managers' attitude, behavior and action that encourages employees to use knowledge, skills and attitudes learned in their actual jobs (Mathieu et al., 1993). Previous research has classified manager support as one of the workplace environment factors (Baldwin \& Ford, 1988; Mathieu et al., 1993; Tziner et al., 2007). As pointed by Mathieu et al. (1993), workplace environment includes such factors as managerial support, peer support, availability of resources, technical and administrative support, and job facilities support. Fundamentally, work environment characteristics focuses on perception of the manager/supervisor support, opportunity to use the skills and knowledge and organizational continuous learning culture and the transfer of training.

Empirically, manager support was found significantly related to training effectiveness (Baldwin \& Ford, 1988; Burke \& Hutchins, 2008; Tziner et al., 2007). They also asserted that work environment is a significant predictor of training effectiveness in which work environment is a proximal factor of training motivation while it is a distal factor of training effectiveness. According to Holton (2005), a wide array of studies related to work environment suggested other related factors that may influence training effectiveness. With regard to manager's supports and training effectiveness links, empirical studies have proved positive relation between these two variables (Mathieu et al., 1993; Tracey \& Tews, 1995).

The positive relation could be explained with a premise assumption that encouragement and positive attitude and behavior of manager are a particularly crucial element in skill application in the job (Mathieu et al., 1993). This is because trainees' skills and knowledge could be applied if a manager believes that their learned skills in a variety of ways such as on the job training and coaching approaches. This stand is supported by Tracey and Thews (1995). Their argument is based on the principle that the benefit of training may be seen immediately in improving employees' performance when managers sincerely give continuous support to employees to apply acquired knowledge and skills. Based on above, the following hypothesis is posited:

H4: Manager support is positively related to OJT training effectiveness.

\section{Research Method}

\subsection{Description of Research}

This study used quantitative approach and questionnaire as a main data collection tool. A survey approach used in this study to seek the self-report data from respondents. This is because the study focused on collecting factual information about individuals and their opinions regarding OJT training, thus, the survey is a highly appropriate approach. In addition, the time needed to prepare a survey form is quick and it can be manageable well also.

The population of the study is 500 staffs from Bank A located in Kuala Lumpur. Simple random sampling technique was used in this study. Bank A has organized the OJT training for their new staffs and also for those staffs who have been with the company over past years to ensure they are still aware of the OJT concepts. Thus, large cost has been allocated to accommodate these trainings among the staffs the create awareness about the OJT training, and the value for money for their expenditure can be measured by the effectiveness of the training provided to them. This can be helpful to the management as well as they can ensure the return of the expenses on providing this OJT training on a monthly basis and ensuring that all the newly-appointed staffs attend this training as a mandatory step in their career progression.

\subsection{Research Framework}

The research framework of this study is based on the discussion of the variables in the literature review. The research framework consists of three independent variables, which are individual characteristics, training content, and manager support. Individual characteristics consist of two dimensions, which are self-efficacy and motivation to learn. Meanwhile, the dependent variable for this study is OJT training effectiveness. The research framework of this study is illustrated in Figure 1. 


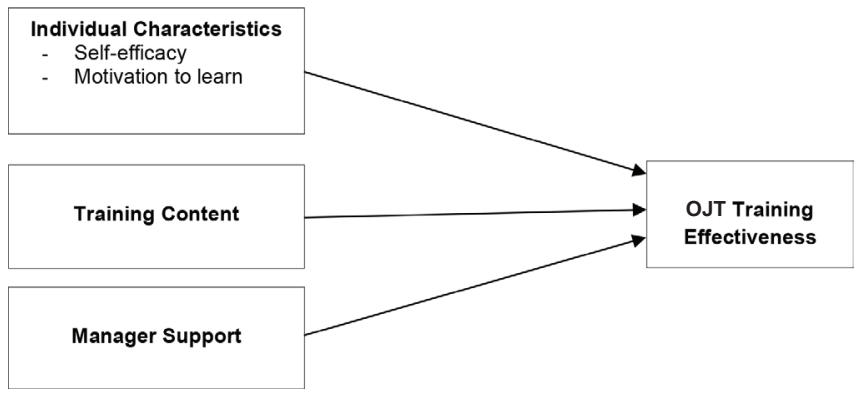

Figure 1: Research Framework

\subsection{Data Collection}

Data was collected by handing over the questionnaire to the bank staffs of Bank A and they were given period of one week to complete the form and return to the researcher. The distribution was done by hand as the researcher can easily meet the respondents and ask for their favor to participate in this research study. During the distribution, the researcher has explained the sections in the questionnaire briefly.

\subsection{Measurement}

\section{OJT Training effectiveness}

OJT training effectiveness is operationalized as employee perceptions of their ability to apply skills and knowledge gained and learned in the OJT to his or her jobs. This construct was measured using 13 items adapted from Campion et al. (1994). 'Improve my knowledge of department's role' and 'enhance my knowledge about organization policies, procedures and practices' were examples of items used in the present study. All the items were measured by using a 5-point Likert scale, from 1 (strongly disagree) to 5 (strongly agree). The Cronbach's Alpha was .89 .

\section{Self-efficacy}

Self-efficacy is operationalized as trainee's belief that he or she can successfully achieve training goals of OJT training and succeeds in the training. Self-efficacy was measured using seven items adapted from Schwarzer and Jerusalem (1995). A 5 -point Likert scale ranging from 1 (not at all true) to 5 (exactly true) was applied to answer each item. Examples of the items are 'I can always manage to solve difficult problems if I try hard enough' and 'I am confident that I could deal efficiently with unexpected events'. The Cronbach's Alpha was .755.

\section{Motivation to learn}

Motivation to learn is operationalized as trainee's desire to participate in OJT training. Four items adapted from Yi and Davis (2003) were used to measure motivation to learn. Examples of items are 'I am very excited to participate in OJT training' and 'I will try to learn as much as I can from OJT training'. All the items were measured using a 5-point Likert scale, from 1 (strongly disagree) to 5 (strongly agree). The Cronbach's Alpha was .711.

\section{Training content}

Training content is operationalized as a trainee's perceived match between the training material used and the training needs and objectives of OJT training. The training content construct was measured by using six items developed by Axtell et al. (1997). Examples of items are 'the training contents of OJT training are related to the needs of my duties', 'the training modules was well programed and completed', and 'I feel enough time was devoted to learning each on the modules'. All the items were measured by a 5-point Likert scale, from 1 (strongly disagree) to 5 (strongly agree). The Cronbach's Alpha was .718.

\section{Manager support}

Manager support is operationalized as the perceived support that a trainee receives from his or her immediate manager for applying knowledge and skills gained from OJT training to his or her job. Six items adapted from Tracey and Tews (2005) were used to measure manager support. Examples of items are "my manager gives recognition to those who apply new knowledge and skills to their work' and 'I agree that feedbacks from the managers are very useful for the transfer of knowledge and skills to my job'. All the items were measured by a 5-point Likert scale, from 1 (strongly disagree) to 5 (strongly agree). The Cronbach's Alpha was .825 .

\section{Results and Discussion}

\subsection{Respondents' Profile}

The respondent's demographic is shown in Table 1. Out of 396 respondents, $70 \%$ were female while $30 \%$ were male. The age of respondents was categorized according to six groups: less than 21 years old, 21 to 25 years old, 26 to 30 years old, 31 to 35 years old, 36 to 40 years old and more than 40 years old. The results also indicated that $53 \%$ respondents were in category of 31 to 35 years old, followed by 22 to 25 years old $(23.5 \%)$.

Most of the respondents were married (67.3\%), followed by single $(22.8 \%)$ and others $(10 \%)$. For the question about years of service in Bank A, the list of given answers was grouped into seven categories: 0-5 years, 6-10 years, 11-15 years, 16-20 years, 21-25 years, 26-30 years and more than 30 years. The findings showed that most of the respondents have been working in Bank A for more than 16 years and less than 20 years $(52.0 \%)$. There was only one respondent who worked more than 26 years and less than 30 years $(0.3 \%)$. Ten respondents were new to Bank A, placed in less than 5 years of service category. Around $84.3 \%$ respondents were from middle management followed by supporting level, which were $10 \%$ of them and lastly top management $(5.8 \%)$. Among them, many respondents had experience in banking sector more than 16 years and less than 20 years. As regards the education level, respondents with diploma qualifications constituted the biggest group, followed by STPM/Matriculation levels. 
Hadziroh IBRAHIM, Md. Lazim Mohd ZIN, Punitha VENGDASAMY /

Table 1: Respondents' profile

\begin{tabular}{|c|c|c|c|}
\hline $\begin{array}{l}\text { Respondents' } \\
\text { Profile }\end{array}$ & & Frequency & Percent \\
\hline \multirow[t]{2}{*}{ Sex } & Male & 119 & 30 \\
\hline & Female & 277 & 70 \\
\hline \multirow[t]{6}{*}{ Age } & $<21$ years old & 37 & 9.5 \\
\hline & $22-25$ years old & 93 & 23.5 \\
\hline & $26-30$ years old & 21 & 5.3 \\
\hline & $31-35$ years old & 210 & 53 \\
\hline & $36-40$ years old & 21 & 5.3 \\
\hline & $>40$ years old & 14 & 3.5 \\
\hline \multirow[t]{3}{*}{ Marital Status } & Married & 266 & 67.3 \\
\hline & Single & 90 & 22.8 \\
\hline & Others & 40 & 10 \\
\hline \multirow{7}{*}{$\begin{array}{l}\text { Years of } \\
\text { Service }\end{array}$} & $<5$ years & 10 & 2.5 \\
\hline & $6-10$ years & 49 & 12.3 \\
\hline & 11-15 years & 61 & 15.5 \\
\hline & $16-20$ years & 206 & 52 \\
\hline & 21-25 years & 2 & 0.5 \\
\hline & 26-30 years & 1 & 0.3 \\
\hline & $31+$ years & 67 & 17 \\
\hline \multirow[t]{3}{*}{ Position } & Top Management & 23 & 5.8 \\
\hline & $\begin{array}{l}\text { Middle } \\
\text { Management }\end{array}$ & 334 & 84.3 \\
\hline & Supporting Level & 39 & 10 \\
\hline \multirow{7}{*}{$\begin{array}{l}\text { Total Years } \\
\text { of services in } \\
\text { Banking }\end{array}$} & $0-5$ years & 10 & 2.5 \\
\hline & 6-10 years & 26 & 6.5 \\
\hline & $11-15$ years & 76 & 19.3 \\
\hline & $16-20$ years & 117 & 29.5 \\
\hline & 21-25 years & 97 & 24.5 \\
\hline & $26-30$ years & 2 & 0.5 \\
\hline & $31+$ years & 68 & 17.3 \\
\hline \multirow[t]{6}{*}{ Education } & PHD & 40 & 10 \\
\hline & Master Degree & 38 & 9.5 \\
\hline & Bachelor Degree & 49 & 12.5 \\
\hline & Diploma & 181 & 45.8 \\
\hline & $\begin{array}{l}\text { STPM/ } \\
\text { Certificate/ } \\
\text { Matriculation/A- } \\
\text { Level }\end{array}$ & 53 & 13.5 \\
\hline & SPM & 35 & 8.8 \\
\hline
\end{tabular}

Table 2: Descriptive Statistic, Scale Reliabilities and Correlations Variables

\begin{tabular}{|c|c|c|c|c|c|c|}
\hline Variables & Mean & SD & SE & ML & $\mathrm{TC}$ & MS \\
\hline $\begin{array}{l}\text { Self- } \\
\text { efficacy } \\
\text { (SE) }\end{array}$ & 4.02 & 2.23 & $(.755)$ & & & \\
\hline $\begin{array}{l}\text { Motivation } \\
\text { to learn } \\
\text { (ML) }\end{array}$ & 3.27 & 1.79 & $\begin{array}{l}.231^{*} \\
(.711)\end{array}$ & & & \\
\hline $\begin{array}{l}\text { Training } \\
\text { content } \\
\text { (TC) }\end{array}$ & 3.87 & 2.12 & $.218^{* *}$ & $\begin{array}{l}.267^{* *} \\
(.718)\end{array}$ & & \\
\hline $\begin{array}{l}\text { Manager } \\
\text { Support } \\
\text { (MS) }\end{array}$ & 3.71 & 1.68 & $.168^{* *}$ & $.311^{* *}$ & $\begin{array}{l}.161^{*} \\
(.825)\end{array}$ & \\
\hline $\begin{array}{l}\text { OJT } \\
\text { training } \\
(\mathrm{OJT})\end{array}$ & 3.27 & 2.56 & $.431^{*}$ & $.371^{* *}$ & $.472^{*}$ & $\begin{array}{c}.255^{\star *} \\
(.89)\end{array}$ \\
\hline
\end{tabular}

Note: ${ }^{*} p<.05,{ }^{* *} p<.01$.

\subsection{Means, Internal Reliability and Correlations}

Table 2 presents the mean, standard deviation, scale reliabilities and correlation coefficient of the study. Cronbach's Alpha values for the adapted scales were selfefficacy $=.755$, motivation to learn $=.711$, training content $=$ .718 , manager support $=.825$ and OJT training $=.89$. In terms of correlations amongst variables, as shown in the table, all four independent variables, namely, self-efficacy $(\mathrm{r}=.431$, $\mathrm{p}<.05)$, motivation to learn $(\mathrm{r}=371, \mathrm{p}<01)$, training content $(\mathrm{r}=.472, \mathrm{p}<.05)$, and manager support $(\mathrm{r}=.255, \mathrm{p}<.01)$, were found positively correlated with OJT training.

\subsection{Multiple Regression Result}

Four hypotheses were tested to identify the relationships between self-efficacy, motivation to learn, training contents, manager supports, and OJT training effectiveness. In order to test the relationships, a multiple regression analysis was carried out. As shown in Table 3, the value R square (.643) explains about $64.3 \%$ of the variability of the dependent variable. The adjusted $\mathrm{R}$ square, adj. $\mathrm{R}^{2}$ can be used to explain the accuracy of the data as well. The results show that the independent variables (self-efficacy, motivation to learn, training content, and manager supports) were significantly related to OJT training effectiveness, $F(3,396)=238.127$, $p<.0005$. Table 3 shows that all independent variables were found to be significantly and positively related to OJT training effectiveness, which are self-efficacy $(\beta=.212$, $p<.05)$, motivation to learn $((\beta=.182, p<.05)$, training content $(\beta=.307, p<.05)$, and manager supports $(\beta=.871, p<.05)$, 
Table 3: Multiple Regression Result

\begin{tabular}{|c|c|c|c|c|c|c|}
\hline \multirow{2}{*}{\multicolumn{2}{|c|}{ Model }} & \multicolumn{2}{|c|}{ Unstandardized Coefficients } & \multirow{2}{*}{$\begin{array}{c}\text { Standardized coefficients } \\
\text { Beta }\end{array}$} & \multirow[t]{2}{*}{$\mathbf{t}$} & \multirow[t]{2}{*}{ Sig } \\
\hline & & B & Std. Error & & & \\
\hline & Constant & .076 & .101 & & 2.331 & .450 \\
\hline & Self -efficacy & .212. & ,035 & .260 & 5.036 & .000 \\
\hline & Motivation to learn & .182 & .041 & .156 & 4.416 & .018 \\
\hline & Training content & .307 & .027 & .257 & 4.329 & .001 \\
\hline & Manager support & .871 & .036 & .915 & 6.136 & .000 \\
\hline & \multicolumn{6}{|c|}{ a. Dependent variable: OJT training effectiveness } \\
\hline & $\begin{array}{l}\mathrm{R}=.802 \\
\mathrm{R}^{2}=.643 \\
\text { Adj. } \mathrm{R}^{2}=.641 \\
\mathrm{~F} \text { value }=238.127\end{array}$ & & & & & \\
\hline
\end{tabular}

thus supporting the hypotheses $\mathrm{H}_{1}, \mathrm{H}_{2} \mathrm{H}_{3}$ and $\mathrm{H}_{4}$. All these variables statistically predicted OJT training effectiveness, $F(3,396)=238.127, p<.0005, R^{2}=.643$, and added statistically significantly to the prediction, $p<.05$. Among all the three factors, manager support shows highly correlated with the effectiveness of the OJT training.

\section{Discussion}

Regarding the relationship between self-efficacy and OJT training effectiveness, the findings show a positive relationship between these two variables. The positive influence of self-efficacy on OJT training indicates that trainees' self-regulation and self-discipline play crucial roles in encouraging employees to apply skills and knowledge learned in OJT training. Seemingly, the findings also imply that employees' judgment of their capabilities to perform successfully in OJT might influence their ability to apply learned skills and knowledge to their actual jobs. Besides that, employees also need to know that in order to succeed in OJT training, employees with high capability to learn and confidence are more likely to be better employees in the workplace. These findings are in line with the idea pointed out by Martin (2010) who posits that employees' efforts to develop self-encouragement in the training would encourage them to apply learned skills and knowledge in the actual jobs.

In examining the relationship between motivation to learn and OJT training effectiveness, the results show that motivation to learn has a significant positive relationship with OJT training effectiveness. This finding implies that trainees' motivation to explore and learn new skills and knowledge during OJT might make positive effects to employees' career progression in the short term or in the future. A reasonable explanation for this positive relationship is that learning-oriented motivation has a positive association with employees' desire to apply skills and knowledge learned in OJT to their actual jobs in organization. As pointed out by Wen and Lin (2014), OJT is a good training method for enhancing motivation among employees to learn new skills and knowledge that are interesting or useful to their career, whether it is short-term skills development or future jobrelated requirement.

In terms of the relationship between training content and OJT training effectiveness, the result demonstrates a positive relationship between these two variables. This is in line with Alias et al. (2019) who claim that training content is crucial to ensure the training content matches the training needs, objectives, skills and knowledge to be taught. Seemingly, the positive result implies that OJT training contents are matches with the job requirements, skills and knowledge that would be applied to employees' jobs. The positive nature of this relationship is also consistent with a justification by Holton et al. (2000) who believe that when the training content is similar to the actual work, the effectiveness of OJT training rises. Similarly, as pointed out by Velada et al. (2007), the effectiveness of OJT could be measured by examining similarity between training contents and job descriptions. Thus, it is not surprising that high similarity and matches between training contents and employees' actual jobs could be used to assess OJT training effectiveness.

In testing the relationship between manager support and OJT training effectiveness, the result reveals that manager support has a positive influence on OJT training effectiveness. This finding indicates that manager's support would have positive effects on their desire and ability to transfer skills and knowledge learned in OJT to their actual jobs. Therefore, 
Hadziroh IBRAHIM, Md. Lazim Mohd ZIN, Punitha VENGDASAMY I

it is crucial for managers to ensure they understand the importance of their involvement, encouragement and support to employees to apply skills and knowledge learned in OJT to their actual jobs. This reasonable explanation is in line with the argument by Mathieu et al. (1993) that positive attitude and behavior of manager is a particularly crucial element in skill application in the job.

Numerous practical implications can be suggested from the study results, particularly for managing OJT training in the banking sector in Malaysia. The findings of the study have expanded knowledge towards the influences of individual characteristics, training content and managers support on OJT training. Additionally, the current study presents an empirically-verified framework for engaging organization's top management in dealing with OJT training, and outlining the crucial roles of employees' self-efficacy and their motivation to lean for encouraging them to apply skills and knowledge gained in the OJT training to their actual jobs. Moreover, the findings showcase precise channels such as training content and manager support through which OJT training can be managed and amplified to foster further mutual benefits between employees and employers. Therefore, the study pinpoints that in order to get employees to apply the best of their skills, knowledge and capabilities at work, training content features are crucial, followed by the perception regarding the manager's support. Following this, HR managers can start their initiative to focus on ways to develop a supportive OJT training environment and engage in activities to continuously support employees for developing skills and knowledge in the workplace.

In spite of achieving its research objectives and offering significant findings, the present study has some limitations. At first, the study adopted cross-sectional design, which restricts drawing causal explanations. Notably, longitudinal study design provides times intervals hence, a longitudinal design may be considered for future, measuring the constructs at different instances to further strengthen the findings of the current study. Moreover, this study also adopted selfreporting. Self-reporting can be seen as another limitation of the present study, which may have inflated the relationships among the variables. This is because self-reports can result in common method variance in behavioral research. Thus, future researchers may possibly employ other strategies such as qualitative techniques or focus group approach.

\section{Conclusion}

This study provides interesting findings on the influence of individual characteristics, training content and manager support on the effectiveness of OJT training. The results indicate that all the factors have positive relationships with OJT training among the staff in Bank A. On the basis of employees' perceived OJT training outcomes, the finding reveal that manager's support has a stronger influence on OJT training effectiveness, followed by self-efficacy, training content, then motivation to learn. This implies that, in an effort to implement OJT training inside an organization, managers should prioritize employees' continuous support, especially through consistent support for encouraging them to apply skills and knowledge learned in OJT training to their actual jobs. The findings also are crystal clear on the importance of employees' ability and desire to learn new skills and knowledge, which are explained and described in the training contents or training modules. Putting all together, the findings in the present study offer valuable knowledge on the influence of employee's factor, training content and manager support on OJT training.

\section{References}

Akhter, A., Hossain, M. U., \& Al Asheq, A. (2020). Influential factors of social entrepreneurial intention in Bangladesh. Journal of Asian Finance, Economics and Business, 7(8), 645651. https://doi.org/10.13106/jafeb.2020.vol7.no8.645

Alias, S. A., Ong, M. H. A., Rahim, A. R. A., \& Hassan, R. (2019). The role of training design factors in influencing training effectiveness among public service employees. International Journal of Academic Research in Business and Social Sciences, 9(5), 898-913. http://dx.doi.org/10.6007/IJARBSS/v9-i5/6016

Axtell, C \& Maitlis, S (1997), Predicting immediate and longer-term transfer of training. Personnel Review, 26, 201-13. https://doi. org/10.1108/00483489710161413

Baldwin T.T. \& Ford, J.K. (1988), Transfer of training: A Review \& directions for future research. Personnel Psychology, 41(1), 63-105.

Burke, L.A., \& Hutchins, H.M. (2008). A study of best practice in training transfer and proposed model of transfer. Human Resource Development Quarterly, 19(2), 107-128. https://doi. org/10.1002/hrdq. 1230

Campion, M.A., Cheraskin, L., \& Stevens, M.J. (1994). Careerrelated antecedents and outcomes of job rotation. Academy of Management Journal, 37, 1518-1542.

EL Hajjar, S. T., \& Alkhanaizi, M. S. (2018). Exploring the factors that affect employee training effectiveness: A case study in Bahrain. SAGE Open, 8(2), 1-12. https://doi. org/10.1177/2158244018783033

Holton, E, F. (2005). Holton's evaluation model: New evidence and construct elaborations. Advances in Developing Human Resources, 7(1), 37-54. https://doi. org/10.1177/1523422304272080

Holton III, E. F., Bates, R. A., \& Ruona, W. E. (2000). Development of a generalized learning transfer system inventory. Human Resource Development Quarterly, 11(4), 333-360.

Kim, J. E. (2019). The impact of creative role identity and creative self-efficacy on employee creativity in the hotel business. 
Journal of Asian Finance, Economics and Business, 6(2), 123133. https://doi.org/10.13106/jafeb.2019.vol6.no2.123

Kraiger, K., Ford, J. K., \& Salas, E. (1993). Application of cognitive, skill-based, and affective theories of learning outcomes to new methods of training evaluation. Journal of Applied Psychology, $78(2), 311-328$

Martin, H. J. (2010). Improving training impact through effective follow-up: techniques and their application. Journal of Management Development, 29 (6), 520-534. https://doi. org/10.1108/02621711011046495

Mathieu, J.E., Tannenbaum, S.I., \& Salas, E. (1992). Influences of individual and situational characteristics on measures of training effectiveness. Academy of Management Journal, 35, 828-847.

Mathis R.L. \& Jackson J.H. (2010). Human Resource Management (13th ed.). Ohio: South-Western College Publishing.

Mathieu, T.E., Martineau, J.W., \& Tannebaum, S.I. (1993). Individual and situational influences on the development of self-efficacy: Implications for training effectiveness. Personnel Psychology, 46(1), 125-147.

Noe, R.A., \& Kodwani, A. D. (2018). Employee Training and Development (7th ed.). Boston, MA: McGraw-Hill Education.

Sahoo, M. \& Mishra S. (2019). Effects of trainee characteristics, training attitudes and training need analysis on motivation to transfer training. Management Research Review, 42 (2), 215238. https://doi.org/10.1108/MRR-02-2018-0089

Schwarzer, R., \& Jerusalem, M. (1995). Generalized self-efficacy scale. Measures in health psychology: A user's portfolio. Causal and Control Beliefs, 1(1), 35-37.

Suminah, S., \& Anantanyu, S. (2020). Empowering poor-households women on productive economy businesses in Indonesia.
Journal of Asian Finance, Economics and Business, 7(9), 769779. https://doi.org/10.13106/jafeb.2020.vol7.no9.769

Tracey, J.B., Tannenbaum, S.I., \& Kavanagh, M.J. (1995). Applying Trained skills on the job: The importance of the work environment. Journal of Applied Psychology, 80(2), 239-252.

Tracey, J.B., \& Tews, M.J. (1995). Training effectiveness: Accounting for individual characteristics and the work environment. Cornell Hotel and Restaurant Administration Quarterly, 36(6), 36-42. https://doi. org/10.1177/001088049503600615

Tziner, A., Fisher, M., Senior, T., \& Weisberg, J. (2007). Effects of trainee characteristics on training effectiveness. International Journal of Selection and Assessment, 15(2), 167-174.

Velada, R., Caetano, A., Michel, J.W., Lyons, B.D., \& Kavanagh, M.J. (2007). The effects of training design, individual characteristics and work environment on transfer of training. International Journal of Training and Development, 11(4), 282294

Wen, M.L.Y. \& Lin, D.Y.C. (2014). Trainees' characteristics in training transfer: The relationship among self-efficacy, motivation to learn, motivation to transfer and training transfer. International Journal of Human Resource Studies, 4(1), 114129. http://dx.doi.org/10.5296/ijhrs.v4i1.5128

Yi, M.Y. and Davis, F.D. (2003). Developing and validating an observational learning model of computer software training and skill acquisition. Information Systems Research, 14, 146-69.

Zhao, X., \& Namasivayam, K. (2009). Posttraining self-efficacy, job involvement, and training effectiveness in the hospitality industry. Journal of Human Resources in Hospitality and Tourism, 8(2), 137-152. https://doi.org/10.1080/15332840802269767 